\title{
PREFACE
}

\section{KARL WIDERQUIST}

This is an odd book with an odd history. Grant and I began working on it in about 2007, but we didn't know who the other one was until 2010. For me, it started when I was at Tulane University shortly after I completed an article called "A Dilemma for Libertarianism," which examines the Lockean attempt to justify private property rights by telling a story of "original appropriation." My argument was that if you tell a slightly different appropriation story, the same principles justify a monarch or a democratic assembly owning all the property. Thus, Lockean principles don't say anything at all about whether property should be private or public. When I explained this argument to a prominent libertarian (or "propertarian," to use this book's term), he responded, "What a colossal counterfactual!"

I thought that was the worst possible response a propertarian could give because their appropriation story is a fanciful tale about rugged individuals who go into "the state of nature" to clear land and bring it into cultivation. Do propertarians actually think this story is true? After thinking over their arguments I realized to some extent the answer is yes. They think at least that there is truth in it, that "private" "property rights" are somehow more natural than public or communal "territorial claims." So, I set out to read a little bit of anthropology and write a short 4,000-word article disproving that utterly ridiculous claim. But over the following nine years that 4,000-word article has grown to a research project involving at least two books, two spinoff articles, an online appendix, and maybe more after that. The original subject of that original article is now one of the topics planned for the second book.

As I read a little more anthropology, I realized that the sources I had started with were not a broad representation of the relevant 
anthropological thought. So, I read some more and began to think about other dubious anthropological claims floating around modern political philosophy. I spent most of the academic year 2007-8 and much of the next (both years at the University of Reading in the United Kingdom) reading anthropology, archaeology, and historynot quite sure what I was looking for, but able to relate most of what I was learning to political philosophy in my field. I probably should have been publishing more articles and trying to get a job, but it was fabulously interesting, telling me stuff about history and about prehistory that I've always wanted to know and that is left out of most history books.

Eventually I settled on a half dozen prominent claims that I thought could be falsified in a long article, or maybe a two-part article: the contractarian claim that everyone is better off in a state society, the propertarian claim that everyone is better off in a society with privatized land, a popular claim that inequality is natural and inevitable, the propertarian claim capitalism delivers greater negative freedom than any other system, and the claim that started me off: the widespread belief that the appropriation story somehow explains something about why some people own all the resources and other people don't.

By 2010, I was working at Georgetown University's campus in Qatar and married to Elizabeth Smith Widerquist, whom I hadn't even met when I started working on this project. She works at XavierLouisiana, which is a long way from Qatar. So, she arranged for me to present my "article" at her university. Two anthropologists from Tulane University sat poker-faced in the front row throughout the presentation. One of them was Grant S. McCall, and it turned out that he had also been working for several years on debunking commonly held misconceptions about prehistory. We eventually decided to combine our efforts and write a book. Our partnership gave me the hope, which you can judge whether we have realized, that this book would not be a philosopher dabbling in anthropology or an anthropologist dabbling in philosophy, but a cross-disciplinary work equally wellinformed of the relevant research on both sides.

When I presented this work to philosophers, I found that it split an audience. One side essentially agreed: the evidence we present falsifies important empirical claims in the relevant theories. The other side didn't disagree that our empirical evidence falsifies the claims; they 
disagreed that the theories in question actually rely on these claims or sometimes that these theories rely on any empirical claims at all.

This split made me realize that this book needs to criticize a clarity issue as much as it needs to criticize a factual issue. Not only does contractarianism rely on questionable claims, most versions of the theory are not entirely clear what those claims are or whether the theory needs them or not. This sent us much more deeply into the history of social contract theory to show that so-and-so's version requires this claim too. I spent more than half of the 2014 calendar year and part of the next reading through political theory pinning down various theorists' positions on the issues we were investigating. The result is five chapters on contractarian and propertarian theory in the following book and an additional 20,000 words or so in an online appendix. Together, we hope this writing demonstrates that despite some equivocation, contractarian theory does require claims of the kind we address.

After this expansion of the project, Grant and I realized we had enough material for two books. And so, for the first book, we concentrated on one issue that combines the contractarian and propertarian claims about the state of nature I had been working on with some of the issues of violence and warfare that Grant was working on. This effort resulted in the book that follows, and we had so much material from the history of political thought that we had to move more than 20,000 words into an online appendix.

We have three claims left to examine in our follow-up book, tentatively titled, The Prehistory of Private Property: And What It Means for Contemporary Capitalism. We hope these two books can contribute both to a better-informed empirical debate and to a clearer normative debate of the theories we address. It's been fun reading all these books and writing what we think about them. I hope you find it worth reading.

\section{GRANT S. McCALL}

Writing this book has been the most difficult project of my career. This is funny because, when I met Karl now the better part of a decade ago and we decided to collaborate, it seemed as if this would be a relatively simple matter of debunking the worst of the early modern period misconceptions about indigenous peoples, as well as somewhat 
later misunderstandings of human prehistory. After so many years of work on this book and a second book in the works to cover the topics left out of this book (not to mention a number of journal articles on related topics), it would be an understatement to say that this project was more complex than either of us ever anticipated.

The reasons for this, however, are perhaps illustrative of some important lessons that I have learned and that I hope readers will take away from this book. As an anthropologist, a good deal of the complexity of writing this book lay in the reconciliation of two rather different ways of looking at human social diversity between the fields of political philosophy and my own discipline. As a scientist, I am interested in documenting and understanding all of the incredible variability in terms of how human societies have organized themselves over the vastness of time and space and the evolutionary processes that have brought these lifeways into being. The value of the anthropological information presented in this book is its relevance to historical efforts to justify the state and private property. Some anthropologists may complain-and some have already - that this project is, therefore, an inherently flawed exercised in comparing apples and oranges; that using anthropological perspectives on human diversity to develop political policy is somehow a doomed effort in fundamental violation of the principles of cultural relativism that have constituted the heart of the discipline for more than a century. To the reader, I assure you that we have spent many long hours thinking about these issues.

Despite our best efforts to present the consensus of the various fields of social science discussed in this book, we are happy to admit that it is not perfect. There will be those in both of our fields that will object to the ways in which we have chosen to tackle the issues examined here. However, just because an intellectual project is hard and just because one's results may not be perfect does not mean that the project is not worth doing. This is especially true when the goal of a project is as important as the one discussed in this book. Philosophical justifications of the state and private property are profoundly important and they have consequences for every person alive on earth today. Recognizing the racist and colonialist biases at the foundations of modern political institutions offers crucial insights on how to improve these institutions and the lives of the least advantaged people in our affluent societies. 
Thus, while some of my fellow anthropologists may have objections to the approaches and tactics we take in this book, I hope they will appreciate the huge importance of the problem. Likewise, I hope that philosophers will (if nothing else) take away from this the inescapable fact that empirical information about human diversity is instrumental to better thinking about a wide range of knowledge. In spite of debates within my field, we can and do know things about both contemporary human variability and the lifeways of our evolutionary ancestors in the deep past. We have learned a lot in researching and writing this book, and we are certain that those who follow us down this interdisciplinary path will likewise be rewarded. 